\title{
IBM APLIKASI LEAN PRODUCTION DAN ELECTRONIC TELESHOPING PADA BISNIS YOGHURT
}

\author{
Aniek Rumijati ${ }^{1}$ \\ Eny Suprapti ${ }^{2}$ \\ Program Manajemen, Universitas Muhammadiyah Malang ${ }^{1}$ \\ Program Studi Akuntansi, Universitas Muhammadiyah ${ }^{2}$
}

\begin{abstract}
The partner company (Rumah Yoghurt and Pure Yoghurt) is a small company that wants to improve the quality and quantity of yogurt products and expand its market share not only in Batu and Malang regencies but can be wider to Malang Raya or East Java. Constraints faced at this time are the production process carried out in a less sterile space (rather open) and the product packaging process is still manual so it needs a rather long packaging time. Both of these greatly affect the quality of yogurt products. The level of product damage can be overcome by carrying out the production process using the lean production concept. In the field of marketing, the company still relies on direct marketing by meeting face to face with customers, and distributing brochures. This method will be more effective if you add promotional media online or electronoic teleshopping by using a company website or company blog as a cheap promotional event with a very wide market share. For this reason, IbM aims to help partners to: (1) produce yogurt products with better quality and high levels of productivity and (2) help in product marketing. The results of this community service program are: (1) Understanding of lean production; (2) Increased business motivation; (3) Installation of $A C$ and Cup Sealers on partners; (4) Making a company blog; (5) Strengthening the marketing department through: a broader collaboration network, more attractive logo design changes, adding flavor variants and product diversification
\end{abstract}

Keywords: Business assistance, Business motivation, Herbal Drinking

\section{PENDAHULUAN}

\section{Analisis Situasi}

Menghadapi persaingan usaha yang semakin ketat, perusahaan harus bisa melakukan pengembangan usaha agar perusahaan dapat maju dan sukses. Pengembangan usaha dapat dilakukan dengan pengembangan proses produksi yang lebih canggih teknologinya, proses produksi yang makin cepat, pemasaran yang lebih luas dan sumber daya manusia yang lebih terampil. Rumah Yoghurt merupakan usaha minuman yang berbahan dasar susu difermentasi. Usaha ini sudah dilakukan sejak 4 tahun yang lalu. Jumlah karyawan tetap sebanyak 4 orang yang terdiri dari bagian produksi 3 orang dan bagian pemasaran 1 orang, sedangkan jika ada permintaan produk meningkat, perusahaan menambah karyawan harian sesuai kebutuhan.

Proses produksi yogurt relatif mudah yaitu dengan menggunakan bahan susu segar yang sudah dipasturisasi kemudian diberi starter dan difermentasi kurang lebih 20 jam. Proses produksi yoghurt memerlukan peralatan dan lingkungan yang bersih, karena hal itu bisa berpengaruh terhadap hasil produksi. Perusahaan ini memproduksi yoghurt plain, es krim yoghurt, es mambo yoghurt. Produksi per hari rata-rata 65 liter yoghurt plain, kemudian diolah dan dikemas menjadi yoghurt siap minum kira-kira 900 cup. Jumlah produksi ini jauh dibawah kapasitas produksi normal (sekitar 150 - 200 liter yoghurt) atau jumlah produksi sekarang kira-kira baru $35 \%$ dari kapasitas normal. Usaha ini sangat potensial untuk dikembangkan karena mendukung program pemerintah dalam meningkatkan kualitas hidup masyarakat Indonesia. Dari sisi internal perusahaan juga masih besar potensi keuntungan dalam bisnis yoghurt. Apalagi sekarang ini belum banyak perusahaan kecil atau menengah yang menggeluti bisnis ini. Saat ini perusahaan yang memproduksi yoghurt dan sudah dikenal masyarakat adalah Yoghurt Cimory, Yakult dan Vitacharm.

Oleh karena itu pengembangan usaha untuk bisnis yoghurt dirasakan sangat diperlukan. Pengembangan usaha dapat dilakukan dari aspek proses produksi maupun pemasaran. Dari aspek produksi masih ada kendala ruang kerja yang kurang steril, sehingga mempengaruhi hasil produksi cepat rusak.

\footnotetext{
${ }^{1}$ rumijati@umm.ac.id

2 e.suprapti@yahoo.com
} 
Dalam kondisi normal yoghurt dapat aman dikonsumsi dalam jangka waktu 5 hari setelah diproduksi. Karena ruang kerja kurang steril tingkat kerusakan produk pernah mencapai $20 \%$ sehingga dapat mengurangi keuntungan yang diperoleh. Perusahaan perlu melakukan upaya-upaya secara berkesinambungan dalam rangka menghilangkan pemborosan. Itulah yang disebut lean production.Dalam bahasa Inggris, Lean memiliki arti ramping atau kurus. Suatu perusahaan dikatakan Lean jika semua aktifitas yang dilakukan hanya aktifitas yang memberikan nilai tambah dari sudut pandang customer, tanpa adanya pemborosan (waste) yaitu segala sesuatu yang selain jumlah minimum peralatan, material, part, dan waktu kerja yang sangat penting untuk kegiatan produksi. Lean merupakan suatu usaha yang berkesinambungan dalam rangka menghilangkan pemborosan (waste) seperti waktu tunggu, gerakan yang tidak perlu, transportasi yang tidak perlu,pekerja yang kurang efektif, dan pemborosan-pemborosan lainnya sehingga meningkatkan nilai tambah (value added) pada produk agar dapat memberikan nilai kepada pelanggan. Tujuan dilakukannya Lean production adalah untuk meningkatkan secara terus menerus customer value melalui peningkatan terus-menerus rasio antara nilai tambah terhadap waste.

Perusahaan mitra memerlukan alat untuk sterilisasi ruang kerja yaitu dengan memberi alat penyejuk udara (Air conditioner/AC) sebagai upaya meningkatkan value bagi pelanggan dan menghilangkan pemborosan. Selama ini ruang kerja dibiarkan terbuka karena tidak ada AC agar udara di dalam ruangan tetap segar, dan ternyata hal ini menyebabkan tingkat kerusakan produk cukup tinggi. Di samping itu, proses pengemasan produk dilakukan secara manual yang perlu waktu cukup lama (padahal produk yoghurt semakin lama terkena udara bebas semakin mudah produk tersebut cepat rusak). Oleh karena itu diperlukan alat pengemas sederhana (cup sealer) yang dapat digunakan untuk mempercepat proses pengemasan produk.

Dari aspek pemasaran, selama ini pemasaran produk dilakukan secara langsung (face to face) atau bertemu langsung dengan pelanggan. Caranya dengan menawarkan langsung ke sekolah-sekolah, toko dan warung. Daerah pemasaran yang dijangkau masih sedikit, hanya di sekitar kecamatan Dau, Blimbing dan Lawang. Model pemasaran seperti ini dikenal dengan istilah direct marketing. Direct marketing merupakan system marketing interaktif yang memanfaatkan satu atau beberapa media iklan dimana perusahaan berkomunikasi secara langsung dengan target customernya. Direct marketing yang paling mudah dilakukan yaitu dengan bertemu langsung dengan calon pelanggan secara face to face yang dibarengi juga dengan penyebaran brosur. Hal seperti ini yang diterapkan pada Rumah Yoghurt. Dengan menggunakan pemasaran langsung ini akan berdampak terhadap omzet penjualan. Penjualannya relatif sulit meningkat atau stagnan dan keuntungan yang diperoleh juga sedikit, oleh karena itu diperlukan pengembangan direct marketing yang sudah diterapkan disesuaikan dengan kemajuan teknologi yaitu dengan menambahkan penggunaan electronic teleshoping.

Direct marketing merupakan komunikasi pemasaran/promosi yang ditujukan langsung kepada konsumen individual dengan tujuan agar pesan-pesan tersebut dapat segera direspon oleh konsumen yang bersangkutan. Sekarang ini direct marketing semakin berkembang dan diminati konsumen. Melalui direct marketing, konsumen dapat memperoleh manfaat berupa penghematan waktu dalam berbelanja, tidak terjebak dalam arus lalu lintas yang semakin padat dan macet, serta semakin sulit mencari tempat parkir kendaraan. Bagi penjual, manfaat yang dapat diperoleh adalah dapat memilih calon pembeli secara selektif, dapat menjalin hubungan baik jangka panjang dengan pelanggan, dan memperoleh peluang baru yang menguntungkan.

Direct marketing mengalami perkembangan yang signifikan pada tahun 1990an, dari model face to face berkembang mengikuti kemajuan teknologi. Perusahaan dapat menggunakan banyak saluran untuk menjangkau calon pembeli dan pelanggan. Yang termasuk direct marketing sekarang adalah pemasaran dengan direct mail (melalui surat), menggunakan catalog (semua produk perusahaan dimasukkan dalam katalog), broadcast media (pemasaran dengan menggunakan media televisi atau radio), print media (pemasaran menggunakan media cetak koran atau majalah), telemarketing (pemasaaran melalui telepon), dan electronic teleshoping atau belanja online (pemasaran menggunakan media komputer dan modem atau menggunakan internet). Dari berbagai cara pemasaran di atas, yang ditawarkan kepada mitra adalah pengembangan pemasaran langsung secara face to face dikembangkan atau ditambah dengan model yang lain yaitu electronic teleshoping. Pemilihan pemgembangan ini lebih ditekankan pada sisi benefit cost (manfaat/keuntungan dan biaya).

Electronic teleshoping yaitu pemasaran dengan menggunakan internet yang dapat diakses langsung oleh pembeli, pembeli dapat berkomunikasi secara instan dengan perusahaan penjual, dapat bertukar pikiran dan memperoleh informasi secara cepat. Manfaat electronic teleshoping bagi pembeli, dapat dengan mudah memperoleh informasi produk tanpa meninggalkan kantor atau rumah mereka. Bagi penjual, dapat memberikan informasi produk dan layanan yang lebih cepat, biaya pemasaran yang lebih rendah, serta dapat menjalin hubungan baik dengan pelanggan. 
Pure Yoghurt juga merupakan usaha minuman yoghurt yang baru beroperasi tahun 2012 di desa Landungsari Dau Malang. Pemilik perusahaan sudah cukup lama menggeluti di bidang pengolahan susu menjadi produk susu olahan. Tetapi usaha secara komersial baru dimulai tahun 2012. Misalnya produk olahan susu yang sering ditangani adalah dodol susu, krupuk susu, yoghurt, permen susu, dan juga keju. Berdasarkan penjelasan pemilik Pure Yoghurt, dari berbagai produk olahan susu tersebut, yang prospeknya baik untuk dikembangkan sekarang adalah yoghurt. Perusahaan ini dijadikan mitra karena menghadapi permasalahan yang hampir sama dengan Rumah Yoghurt yaitu ingin memperbaiki proses produksi agar produknya tidak cepat rusak dan mengembangkan model pemasaran yang lebih modern dan lebih dapat menjangkau kepada konsumen sasaran. Konsumen sasaran dari Pure Yoghurt sekarang ini lebih difokuskan pada amal usaha (unit bisnis) organisasi massa, misalnya ke sekolah-sekolah Muhammadiyah, sekolahsekolah NU dan juga ke beberapa pondok pesantren yang ada di kota Malang. Karena pasar pada segmen ini bila digarap dengan baik potensinya juga tidak kalah dengan segmen pasar pada masyarakat umum.

Adanya penggunaan aplikasi electronic teleshoping, diharapkan perusahaan dapat lebih dikenal masyarakat, omzet penjualan dapat meningkat, karyawan perusahaan perlu ditambah sehingga dapat mengurangi tingkat pengangguran dan masyarakat dapat mengkonsumsi minuman yang lebih sehat.

\section{Identifikasi dan Perumusan Masalah}

Berdasarkan gambaran analisis situasi diatas, dapat diidentifikasi permasalahan sebagai berikut :

1. Proses produksi dilakukan di ruang kerja yang kurang steril sehingga banyak bakteri merugikan yang masuk, bakteri ini dapat menyebabkan kerusakan pada produk yoghurt.

2. Proses pengemasan dilakukan secara manual, sehingga proses pengemasan memerlukan waktu yang lama. Hal ini juga dapat menyebabkan kerusakan pada produk yoghurt.

3. Sistem pemasaran yang dijalankan saat ini kurang menarik dan kurang agresif, sehingga penjualan kurang meningkat tajam.

4. Daerah pemasaran masih sempit karena produk perusahaan kurang dikenal masyarakat.

\section{Tujuan Kegiatan.}

Tujuan kegiatan IbM ini untuk :

1. Meningkatnya pemahaman yang lebih baik tentang lean production,

2. Meningkatnya motivasi bisnis mitra,

3. Pemasangan AC di ruang produksi,

4. Penggunan cup sealer sebagai alat pengemas,

5. Perbaikan dalam sistem pemasaran dengan menggunakan electronic teleshoping dengan membuatkan website untuk mendisplay produk dan sarana promosi perusahaan.

\section{Manfaat Kegiatan :}

Kegiatan pengabdian masyarakat pada mitra ini diharapkan memberikan manfaat bagi mitra untuk meningkatkan produksi, kualitas produk lebih baik, tingkat kerusakan produk dapat ditekan dan penjualan dapat meningkat serta pendapatan dari mitra kerja dapat meningkat.

Secara ringkas luaran yang diharapkan dilihat pada tabel 1 dibawah ini.

\section{MATERI DAN METODE PELAKSANAAN}

Metode Pelaksanaan yang digunakan sebagai berikut:

1. Ceramah dan Diskusi: untuk memberikan motivasi dan pemahaman tentang pentingnya bisnis modern yang meliputi bisnis offline dan online, proses produksi yang cepat dan higienis untuk produksi yoghurt serta pemasaran online melalui internet.

2. Pemasangan $\mathrm{AC}$ di ruang produksi

3. Uji coba Cup sealer

4. Proses produksi di ruang produksi baru (yang sudah ada AC nya) dan pengemasan dengan menggunakan cup sealer.

5. Pelatihan Pembuatan website yaitu memberikan pelatihan dasar-dasar pembuatan web yang menarik.

6. Praktek operasional website

7. Pendampingan, dilakukan untuk perusahaan mitra yang mengalami kendala dalam penggunaan peralatan produksi dan electronic teleshoping.

Secara khusus metode yang digunakan dalam program ini adalah Penerapan Teknologi Tepat guna 
yang sederhana sehingga mitra dapat dengan mudah memggunakannya,

pelatihan pembuatan web site perusahaan, pembinaan, pendampingan perusahaan mitra serta bantuan alat pengemas gelas ( cup sealer) dan AC.

Bagan 1

Kerangka Pemecahan Masalah

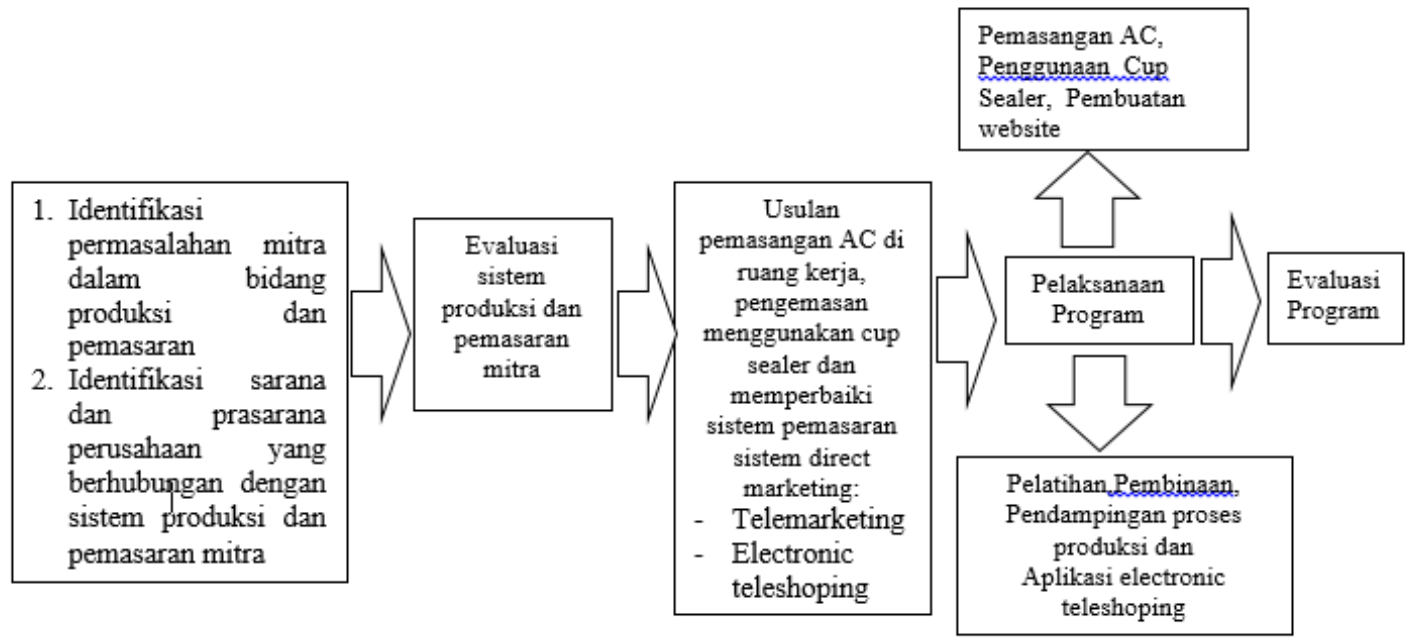

\section{HASIL DAN PEMBAHASAN}

Hasil yang dicapai dari program pengabdian masyarakat ini adalah:

1. Sharing dengan pemilik perusahaan tentang lean production system dan Pelatihan Motivasi Bisnis.

Lean production merupakan satu sistem produksi yang berisi kegiatan-kegiatan yang didesain secara terintegrasi untuk menghasilkan produk yang bernilai tinggi bagi konsumen dengan pencapaian volume produksi yang tinggi dan eliminasi dari kesia-siaan. Sesuatu yang tidak menambah nilai dari produk itu dianggap kesia-siaan, lebih ekstrim lagi dikatakan bahwa kegiatan yang menurut konsumen tidak menambah nilai produk dapat dikatakan kesia-siaan. Ada 7 jenis kesia-siaan dalam proses produksi (Heizer and Render, 2004) :

1. Kesia-siaan dari produksi yang berlebihan

2. Kesia-siaan dari waktu menunggu

3. Kesia-siaan transportasi

4. Gerakan yang sia-sia

5. Kesia-siaan dari produk cacat

6. Kesia-siaan persediaan

7. Kesia-siaan proses

Dari hasil sharing dengan pemilik, dan melalui pengamatan langsung saat proses produksi dapat dikatakan semua proses berjalan efisien. Sebelum dilakukan proses pembuatan Yoghurt semua peralatan sudah disiapkan, kemudian pemesanan bahan baku (susu segar) sesuai dengan jumlah yoghurt yang akan diproduksi. Tidak ada waktu tunggu dan gerakan sia-sia. Tetapi dari hasil diskusi dengan pemilik disimpulkan bahwa terdapat 2 permasalahan utama, yaitu aspek produksi dan aspek pemasaran. Di bidang produksi, ditemui bahwa terdapat permasalahan tentang kualitas produk yaitu produk yang dihasilkan kurang awet (hanya bertahan 1 minggu di lemari pendingin), ini disebabkan suhu ruangan yang suhunya berubah-ubah dengan ruangan agak terbuka. Bahkan dalam beberapa kasus terjadi kerusakan produk hingga $20 \%$.

Selain itu permasalahan lainnya adalah dalam bidang pemasaran, yaitu penjualan selama ini hanya dilakukan secara langsung atau face to face, sehingga penjualan belum optimal, untuk itu diperlukan pemasaran yang lebih efektif. Hal ini memperkuat pengamatan awal yang digunakan sebagai dasar penetapan analisis situasi.

2. Mengadakan Pelatihan Motivasi Bisnis.

Berdasarkan hasil diskusi dengan pemilik, maka diperlukan sosialisasi tentang lean production kepada pegawai bagian produksi dan pelatihan motivasi bisnis modern. Pelatihan motivasi 
yang dilakukan dimaksudkan untuk penyegaran dan tambahan pengetahuan. Para pegawai sudah mempunyai etos kerja yang baik, sehingga dengan adanya pelatihan motivasi bisnis menambah semangat mereka (pekerja) untuk dapat menghasilkan produk yang lebih baik kualitasnya. Dari pelatihan tersebut diperoleh pemahaman yang lebih baik tentang perlunya proses produksi yang higienis dan perlunya lean production, adanya motivasi yang kuat dalam menjalankan bisnis setelah mengikuti pelatihan karena telah diberikan pemahaman bahwa usaha sangat potensial untuk dikembangkan dan upaya untuk meningkatkan pemasaran dengan lebih efektif.

3. Pemasangan AC dan Cup sealer

Pada awal bulan Juni 2014, diadakan survey ke toko AC dan Cup Sealer ke beberapa toko, untuk memperoleh peralatan yang sesuai dengan kebutuhan. Survey bertujuan untuk membandingkan peralatan yang akan dibeli dari segi harga dan dan kemanfaatan. Setelah melalui beberapa pertimbangan, maka pada tanggal 17 Juni 2014 diadakan pembelian AC dan Cupsealer sekaligus dipasang pada tempat usaha. AC digunakan untuk mensterilasisi ruang produksi agar suhu ruang tetap stabil dan berdampak terhadap kualitas hasil produksi, sedangkan Cup sealer digunakan sebagai alat untuk menutup gelas menggunakan mesin, sehingga diperoleh pengemasan dengan lebih cepat.
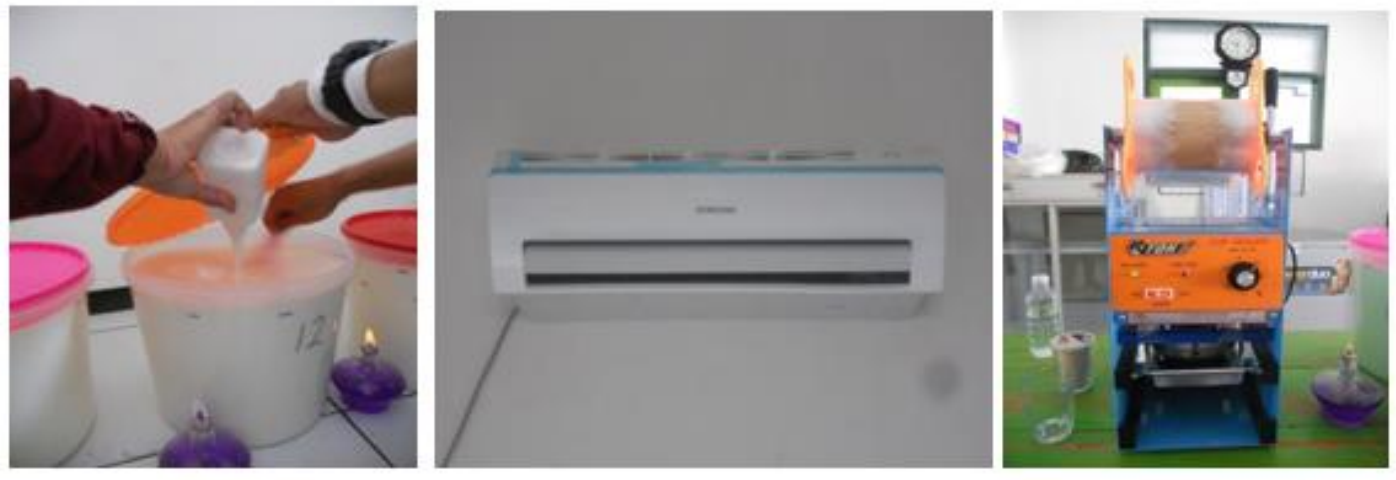

4. Melakukan uji coba proses produksi

Adanya peralatan yang baru, harus diadakan pengujian terlebih dahulu. Uji coba produksi bertujuan untuk mencoba cup sealer yang baru dengan ruangan yang telah dipasang AC. Uji coba dilaksanakan setelah pemasangan peralatan yang baru telah tuntas. Setelah diadakan proses produksi yang baru , maka dari sisi kuantitas, pengemasan dapat dilakukan dengan lebih cepat, sehingga dalam sehari terjadi peningkatan produksi dari 900 cup meningkat menjadi 1500 cup yogurt. Sedangkan dari aspek kualitas maka yogurt jadi yang semula hanya mampu bertahan selama 1 minggu dalam lemari pendingin, sekarang menjadi tahan 1 bulan dalam lemari pendingin tanpa mengurangi kualitas produk. Peningkatan secara kuantitas dan kualitas produk sangat menguntungkan bagi perusahaan. Jumlah peningkatan hasil produksi dengan kualitas produk yang lebih tahan lama akan memperluas jangkauan daerah pemasaran. Selama ini daerah pemasaran sangat terbatas, selain karena pemasaran face to face kurang efekif, tetapi juga karena daya tahan produk yang relative terbatas. Jika yogurt dikrimkan pada daerah pemasaran yang agak jauh maka terkendala dengan daya tahan (keawetan) produk yang terbatas.

5. Pelatihan Pembuatan Blog perusahaan

Perusahaan memerlukan promosi untuk meningkatkan penjualan. Salah satu cara yaitu melalui pembuatan Web site perusahaan. Oleh karena itu pelatihan aspek pemasaran dan pembuatan web dilaksanakan. Karena sumberdaya manusia atau tenaga yang kurang mendukung, maka yang semula direncanakan pembuatan web diganti dengan pembuatan blog. Pelatihan pembuatan Blog diikuti oleh karyawan dan manajer mitra. Pada pelatihan, dijelaskan pentingnya Mitra mengadakan kegiatan pemasaran yang lebih efektif dengan mengubah pemasaran secara langsung atau face to face dengan strategi pemasaran yang lebih efektif. Direct Marketing melalui teleshopping marketing digunakan untuk mengatasi permasalahan selama ini. Selain itu pada pelatihan juga disarankan untuk membuat desain produk yang lebih baik dan penambahan variasi rasa serta difersifikasi produk. Dari hasil pelatihan diperoleh hasil: Dibuatnya blog perusahaan dengan alamat situs : rumahyoghurt.blog.com dan pureyoghurt.blog.com

6. Pendampingan pada mitra 
Pendampingan dilaksanakan secara kontinyu untuk memantau perkembangan usaha mitra. Pendampingan diadakan sebanyak 3 kali dan dilaksanakan secara bertahap hingga diperoleh hasil sesuai yang diharapkan.

7. Penguatan pada bagian pemasaran dengan membuat jaringan kerja sama dengan agen dan toko-toko dan mini market.

Dalam upaya meningkatkan pemasaran, selain mempromosikan melalui bog perusahaan, juga membuat jaringan kerjasama dengan agen, toko dan nimimarket. Produk didistribusikan melalui agen-agen ke toko-toko, sekolah-sekolah, minimarket ataupun unit-unit usaha kecil lainnya. Yogurt dikirim melalui box khusus agar yogurt tidak rusak dan kualitas tetap terjaga. Dengan memperbanyak agen dan memperluas jaringan ini maka penjualan meningkat secara signifikan.

8. Menambah varian produk

Berdasarkan riset pasar dan juga informasi pada saat pelatihan dibidang pemasaran, maka agar penjualan dapat ditingkatkan dan agar lebih disukai oleh konsumen, maka perusahaan menambah varian rasa dari 4 varian rasa yaitu : melon, leci, strawbery dan coklat menjadi 8 rasa yaitu : jambu, markisa, jeruk, pisang, anggur, melon,leci dan strawbery Selain itu diadakan diversifikasi produk, produk yang dihasilkan selain yogurt adalah keju, permen susu, mentega, pizza, es krim

9. Perubahan desain logo baru yang lebih menarik

Kemasan sebuah produk merupakan salah satu unsur yang mempengaruhi banyaknya penjualan atau minatnya konsumen terhadap produk tersebut. Walaupun tujuan atau fungsi utama dari adanya kemasan produk adalah, untuk melindungi produk dari goresan atau cacat produk yang membuat produk menjadi rusak, tetapi kemasan, taerutama logo produk dapat digunakan sebagai daya tarik dan promosi,oleh karena kemasan dan desain yang menarik menjadi hal yang penting. Berdasarkan riset pasar, maka desain produk diganti dari yang lama menjadi desain baru yang lebih menarik.

Dari hasil yang telah dicapai diatas, dapat diringkas luaran yang diperoleh dari kegiatan pengabdian IbM Aplikasi Lean Production dan Electronic Teleshoping pada Bisnis Yogurt ini, ditunjukkan pada table 1 dibawah ini:

Tabel 1

Perbandingan Capaian Hasil

\begin{tabular}{|c|c|c|c|}
\hline No & Capaian & Sebelum & Sesudah \\
\hline 1 & $\begin{array}{l}\text { Pemahaman mitra tentang } \\
\text { perlunya motivasi bisnis dan } \\
\text { lean production }\end{array}$ & Belum paham & Pemahaman meningkat \\
\hline 2 & Peralatan (AC) & Tidak ada & Pemasangan AC 2 buah \\
\hline 3 & $\begin{array}{l}\text { Penggunaan Cup Sealer (untuk } \\
\text { pengemasan) }\end{array}$ & Tidak ada & Penggunaan Cup Sealer 2 buah \\
\hline 4 & Peningkatan jumlah produk & 900 cup & \pm @ 1500 cup per hari \\
\hline 5 & Pembuatan Blog perusahaan & Tidak ada & $\begin{array}{l}2 \text { situs dengan alamat: } \\
\text { rumahyoghurt.blog.com } \\
\text { pureyoghurt.blog.com }\end{array}$ \\
\hline 6 & Kualitas /daya tahan produk & $\begin{array}{l}1 \text { minggu dalam } \\
\text { lemari pendingin }\end{array}$ & 1 bulan dalam lemari pendingin \\
\hline 7 & $\begin{array}{l}\text { Penambahan variasi rasa dari } 4 \\
\text { jenis menjadi } 8 \text { variasi dan ada } \\
\text { rencana perubahan logo baru } \\
\text { yang lebih menarik }\end{array}$ & $\begin{array}{l}4 \text { varian (melon, leci, } \\
\text { strawbery dan coklat) }\end{array}$ & $\begin{array}{l}8 \text { varian (jambu, markisa, jeruk, } \\
\text { pisang, anggur, melon,leci dan } \\
\text { strawbery) }\end{array}$ \\
\hline 8 & Perubahan desain produk & Logo lama & Logo baru yang lebih menarik \\
\hline
\end{tabular}

\section{KESIMPULAN DAN SARAN}

Berdasarkan kegiatan pengadian masyarakat program IbM Aplikasi Lean Production dan Electronic

Teleshoping yang telah dilaksanakan maka dapat disimpulkan sebagai berikut :

1. Proses produksi sudah berjalan dengan baik, adanya penambahan peralatan AC dan Cup sealer telah dapat meningkatkan kuantitas dan kualitas yogurt yang dihasilkan. 
2. Motivasi berusaha lebih meningkat karena pemahaman yang lebih baik tentang proses produksi, ditunjang dengan peralatan yang mendukung dan Ruang produksi yang lebih steril

3. Produk lebih hygien dengan penggunaan Cup sealer, dan daya tahan produk lebih lama

4. Peningkatan jumlah produk yang dihasilkan dengan kualitas yang lebih baik

5. Daerah pemasaran dapat lebih luas dibandingkan dengan sebelumnya, dengan jaringan kerjasa mamelalui toko, agen dan minimarket yang lebih banyak.

\section{Saran}

1. Bagian produksi perlu melakukan perbaikan yang terus menerus agar dapat beroperasi lebih efisien dan efektif.

2. Bagian pemasaran masih tetap perlu memperluas jaringan kerja sama dengan berbagai pihak agar penjualan dapat lebih meningkat

3. Perlu dikembangkan media pemasaran yang tepat sasaran.

4. Perlu mengadakan penelitian lebih lanjut untuk meningkatkan daya tahan (tingkat keawetan) produk, agar yogurt dapat lebih tahan lama dan awet, sehingga pemasaran dapat diperluas.

\section{UCAPAN TERIMAKASIH}

Ucapan terimakasih terutama disampaikan pada Dirjen Dikti yang telah memberikan dana kegiatan pelaksanaan program Pengabdian Masyarakat ; Rektor Universitas Muhammadiyah Malang ; Dekan Fakultas Ekonomi dan Bisnis; Direktur DPPM yang telah memberi fasilitas untuk pelaksanaan pengabdian ini.

\section{REFERENSI}

Duncan, Tom. (2004) IMC: Using Advertising \& Promotion to Build Brand. First Edition. McGraw-Hill, Inc. Fahrur Ahmad. (2014). Pentingnya Sebuah Kemasan Produk Dalam Pemasaran

Groover Mikell P., (2001). Automation, Production System and Computer Integrated Manufacturing, Second Edition, Prentice Hall, New Jersey,

Heizer, Jay and Barry Render. (2004). Principles of Operations Management $5^{\text {th }}$ Edition. New Jersey: Pearson Education

Holweg, Matthias (2007). The Genealogy Of Lean Production. Journal of Operations Management. 25 (2): 420-437

Kotler, Philip and Kevin Lane Keller. (2012) . Marketing Management 13. New Jersey: Pearson Prentice Hall,Inc Wahyuni, dkk. (2011).Pelatihan Kewirausahaan Bisnis Yoghurt dan Pizza pada PCA Dau Malang, Laporan Pengabdian UMM. 
